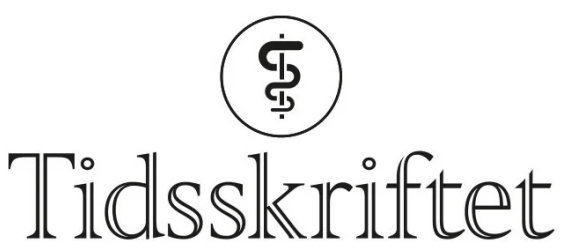

DEN NORSKE LEGEFORENING

\title{
Vi trenger en ny strategi for leversykdom
}

\section{KRONIKK}

\section{METTE VESTERHUS}

mette.namdal.vesterhus@haraldsplass.no

Mette Vesterhus er spesialist i indremedisin og i fordøyelsessykdommer, overlege ved

Gastromedisinsk seksjon, Haraldsplass Diakonale Sykehus og førsteamanuensis ved Klinisk institutt 2, Universitetet i Bergen. Hun er prosjektleder for Nasjonalt nettverk for autoimmune leversykdommer og styremedlem i Norsk gastroenterologisk forenings interessegruppe for leversykdommer.

Forfatteren har fylt ut ICMJE-skjemaet og oppgir følgende interessekonflikter: Hun har mottatt foredragshonorar fra Siemens Healthineers.

\section{KRISTIN KAASEN JØRGENSEN}

Kristin Kaasen Jørgensen er spesialist i indremedisin og i fordøyelsessykdommer, overlege ved Gastromedisinsk avdeling og leder for Seksjon for leversykdommer på Akershus universitetssykehus. Hun er leder av Norsk gastroenterologisk forenings interessegruppe for leversykdommer og styremedlem i Nasjonalt nettverk for autoimmune leversykdommer. Forfatteren har fylt ut ICMJE-skjemaet og oppgir ingen interessekonflikter.

\section{SVEIN OSKAR FRIGSTAD}

Svein Oskar Frigstad er spesialist i indremedisin og i fordøyelsessykdommer og seksjonsoverlege ved Gastromedisinsk avdeling, Bærum sykehus, Vestre Viken. Han er styremedlem i Nasjonalt nettverk for autoimmune leversykdommer.

Forfatteren har fylt ut ICMJE-skjemaet og oppgir følgende interessekonflikter: Han har mottatt konsultasjonshonorar fra Tillotts Pharma, Janssen-Cilag, Takeda, Bristol Myers Squibb og Gilead samt foredragshonorar fra Pharmacosmos og Bristol Myers Squibb.

\section{JOHN WILLY HAUKELAND}

John Willy Haukeland er spesialist i indremedisin og i fordøyelsessykdommer og overlege ved Gastromedisinsk avdeling, Oslo universitetssykehus, Ullevål. Han er styremedlem i Norsk gastroenterologisk forenings interessegruppe for leversykdommer. Forfatteren har fylt ut ICMJE-skjemaet og oppgir ingen interessekonflikter.

\section{TOM HEMMING KARLSEN}

Tom Hemming Karlsen er spesialist i indremedisin og i fordøyelsessykdommer, professor ved Universitetet i Oslo og overlege ved Avdeling for transplantasjonsmedisin, Seksjon for fordøyelsessykdommer, Oslo universitetssykehus, Rikshospitalet. Han er senterleder for Norsk senter for primær skleroserende kolangitt og har nylig ledet en EASL-Lancet-kommisjon for leversykdommer.

Forfatteren har fylt ut ICMJE-skjemaet og oppgir ingen interessekonflikter. 


\section{Dødeligheten av leversykdom øker i Europa på grunn av høyt alkoholforbruk, overvekt og diabetes type 2. «Leverprøver» er lite treffsikre for å finne pasientene som trenger tidlig intervensjon. Vi skisserer en ny tilnærming til denne voksende pasientgruppen.}

Leversykdom er nå den nest vanligste årsaken til tapte arbeidsår i Europa, kun slått av iskemisk hjertesykdom (1). En rykende fersk Lancet-rapport viser at kombinasjonen av overvekt og det høyeste inntaket av alkohol i verden nå skaper en negativ utvikling $\mathrm{i}$ Europa. Dårlig definerte pasientforløp, mangelfullt samarbeid mellom ulike deler av primær- og sekundærhelsetjenesten samt sosiale stigma knyttet til leversykdommer bidrar til at pasienter med signifikant leverfibrose ikke blir fanget opp. Ulikhet i helse, et satsningsområde for Legeforeningen, rammer hardt når det gjelder leversykdom: Lav sosioøkonomisk status er forbundet med økt forekomst av en rekke risikofaktorer for kronisk leversykdom og primær leverkreft, som helseskadelig alkoholinntak, bruk av rusmidler, overvekt - med ledsagende stigmatisering.

For å bedre situasjonen må helsetjenesten foreta radikale endringer. Vi må satse på forebygging $\mathrm{i}$ et folkehelseperspektiv. Vi trenger et system for å identifisere risikopasienter og tilby behandling før en tilstand progredierer til avansert leversykdom.

\section{Overvektsepidemien gir leverkreft}

Omkring en fjerdedel av befolkningen både globalt og i Europa har leversteatose (fettlever) (2). Tall fra den norske HUNT3-studien indikerer høy forekomst av overvektsrelatert leversteatose også i Norge (3). Vi forventer betydelig økt forekomst av avansert leversykdom og hepatocellulært karsinom med den økende forekomsten av overvekt. Selv om et mindretall av de overvektige opplever slik progrediering, blir antallet stort fordi utgangstallet er høyt. Vi ser allerede økende antall levertransplantasjoner som følge av overvekts- og alkoholrelatert leversykdom i Norge. Ved overvekt opptrer hepatocellulært karsinom også uten cirrhose. I USA er overvektsrelatert leversykdom nå den vanligste indikasjonen for levertransplantasjon, og indikasjonen øker også hos ungdom (4). Sykdomsbyrden for avansert leversykdom knyttet til overvekt vil dobles i perioden 2016-30, med enorme konsekvenser - for Europa estimert til over 35 milliarder euro i direkte kostnader og ytterligere 200 milliarder euro i samfunnsøkonomiske tap (1).

Den aldersjusterte prevalensraten for primær leverkreft på bakgrunn av overvektsrelatert leversykdom er doblet de siste zo årene. Primær leverkreft er nå den kreftsykdommen med den tredje høyeste mortaliteten på verdensbasis. Påvisning i tidlig stadium gir gode muligheter for kurativ behandling og sparte leveår.

\section{Overhenvisning og underdiagnostikk}

Hepatitt C kan nå kureres. Pågående randomiserte fase III-legemiddelstudier vil snart resultere i effektiv medikamentell behandling av både autoimmune og overvektsrelaterte leversykdommer. Da kan vi ikke ignorere «lett forhøyede leverprøver».

\section{«Vi kan ikke ignorere 'lett forhøyede leverprøver'»}

Samtidig er det vi i hverdagen omtaler som «leverprøver», lite treffsikkert. Blant det enorme antallet pasienter med steatose utvikler bare et fåtall avansert leversykdom. Transaminasemålinger har dårlig sensitivitet som screeningmetode for fibrose og underestimerer prevalensen av både alkoholrelatert og overvektsrelatert leversykdom (2. 
5). Blant pasienter med steatose er det ikke uvanlig med moderat forhøyede transaminaseverdier $(<120 \mathrm{U} / \mathrm{L}$ ), mens disse er normale hos mange (opptil $91 \%$ ) pasienter med cirrhose (ㅁ). De vil imidlertid fanges opp med enkle algoritmer utregnet fra ordinær biokjemi.

Ved kroniske leversykdommer er fibrose den klart viktigste prognostiske faktoren og det springende punktet for valg av strategi og tjenestenivå. Vi som jobber med leversykdommer, må tydelig formidle hvilken algoritme som bør brukes for påvisning av leverfibrose og når spesifikke fibrosetester eller leverstivhetsmåling (elastografi) bør tas. Vi bør også gi klare retningslinjer for hvilke pasientgrupper som bør ivaretas av spesialisthelsetjenesten. Mangelen på en klar strategi bidrar til at mange personer med klinisk signifikant leversykdom ikke fanges opp - for eksempel blant pasienter med type 2diabetes. En betydelig andel av disse har leverfibrose.

\section{Risikogrupper}

Alle pasienter med fedme eller metabolsk syndrom bør sjekkes for leversykdom, slik de europeiske foreningene for diabetes, overvekt og leversykdommer anbefaler i en felles veileder (.7.). Prevalensen av steatose er svært høy (75-92\%) ved fedme (BMI>30) og over $90 \%$ ved sykelig overvekt (BMI > 35) (1). Type 2-diabetes utgjør en særlig risiko, da én av åtte med denne diagnosen utvikler avansert fibrose (ㅁ).

\section{«Mangelen på en klar strategi bidrar til at mange personer med klinisk signifikant leversykdom ikke fanges opp»}

Personer med helseskadelig alkoholinntak bør også sjekkes for leverfibrose ved regelmessige kontroller. Underdiagnostikken er svært høy. En studie avdekket at kun en fjerdedel av pasientene med alkoholrelatert cirrhose ble diagnostisert før dekompensert stadium (1). Samtidig overvekt og høyt forbruk av alkohol, også lavere nivåer enn terskelverdiene for helseskadelig alkoholinntak, er forbundet med særlig økt risiko for fibroseutvikling $(9, \underline{10})$.

\section{Moderne risikovurdering - hvem skal henvises?}

Helseøkonomiske studier viser at sykdomsjakt (case-finding) i risikogrupper og en flertrinns triagering for avansert fibrose er kostnadseffektivt. Flere personer med avansert leversykdom identifiseres, og en større andel av dem som ikke trenger spesialistoppfølging, allokeres til videre oppfølging i primærhelsetjenesten. Primærhelsetjenesten, og hjerte-, overvekts- og diabetespoliklinikkene, blir sentrale for å identifisere pasienter i risikogruppene ved hjelp av standardiserte leverprøver og fibrosetesten FIB-4 (ramme 1 og ramme 2).

\section{Ramme 1 Standardisert leverprøvepanel}

\section{Standardisert leverprøvepanel bør minimum inneholde:}

Alaninaminotransferase (ALAT)

Aspartataminotransferase (ASAT)

Alkalisk fosfatase (ALP)

Gamma-glutamyltransferase (GT)

Bilirubin

Blodplater 


\section{Ramme 2 FIB-4-test}

\section{Fibrosetesten FIB-4 kan kalkuleres ved hjelp av formelen:}

FIB-4 $=($ alder $[a ̊ r] \times$ ASAT $) /\left(\right.$ blodplater $\left.\left[10^{9} / \mathrm{L}\right] \times \sqrt{\text { ALAT }}\right)$

FIB-4 $<1,3$ kan utelukke avansert fibrose.

Pasienter med forhøyet FIB-4-skår bør henvises for videre vurdering med mer spesifikke fibrosemarkører (f.eks. forsterket leverfribrosetest (enhanced liver fibrosis test, ELF-test)) eller leverstivhetsmåling.

Bildediagnostikk og utredningsprøver med tanke på andre vanlige årsaker til leversykdom (immunglobuliner, autoantistoffer og virusserologi) bør fortsatt tas ved forhøyede verdier på leverprøver eller fibrosetest, men normale prøveverdier skal ikke forhindre vurdering av fibrose. Dersom fibrosetest utelukker avansert fibrose og pasienten tilhører en risikogruppe, kan pasienten følges videre i primærhelsetjenesten med jevnlig kontroll av leverprøver og FIB-4-test. Øvrige pasienter henvises til gastroenterologisk vurdering.

\section{Fibrosevurdering}

FIB-4-test fremheves nå som et godt valg for første evaluering av fibrose ved kroniske leversykdommer. FIB-4-skår regnes enkelt ut på bakgrunn av ASAT, ALAT, blodplater og alder, og er dermed billig og tilgjengelig. Analysen reflekterer stadium av leversykdom.

For å forbedre risikostratifisering anbefales det i en nylig internasjonal veileder at FIB-4skår gis automatisk fra laboratoriet både ved mistenkt leversykdom og for risikogrupper i allmennpraksis (11). Lav FIB-4-skår $(<1,3)$ utelukker avansert leverfibrose med høy negativ prediktiv verdi hos voksne. Disse kan følges i allmennpraksis med livsstilsråd, leverprøver og repetert FIB-4-test etter 1-3 år. Høyere verdier $(\geq 1,3)$ bør føre til videre undersøkelser. Slike verdier er også rapportert som en sterk prediktor for utvikling av hepatocellulært karsinom ved overvekt og steatose.

I en studie fanget implementering av FIB-4-testing ved årskontroll for type 2-diabetes opp 20 pasienter som fikk bekreftet avansert leversykdom ved påfølgende spesialistvurdering, mot 3 pasienter basert på standard oppfølging (oddsrate 6,71, $p=0,002$ ) (므). FIB-4-test kan imidlertid ikke brukes til å stille diagnosen cirrhose, og serumbaserte fibrosetester er generelt dårlig validert hos barn. Pasienter med lav FIB-4-skår, men likevel sterk mistanke om leversykdom, bør derfor henvises til spesialist.

\section{ELF-test og leverstivhetsmåling}

Ved forhøyet FIB-4-skår bør man i andrelinjetjenesten utføre fibrosevurdering med patenterte fibrosetester eller leverstivhetsmåling med elastografi. Lancet-kommisjonen går et skritt lenger og anbefaler dette direkte ved bl.a. type 2-diabetes eller alkoholoverforbruk $(1,11)$. Patenterte fibrosetester måler faktorer som aktivt inngår i fibrogenesen og er mer presise enn FIB-4-test eller andre indirekte fibrosetester. Foreløpig er ingen patenterte fibrosetester tilgjengelige i Norge. 
«Vi oppfordrer laboratorietjenesten ved norske sykehus til å sørge for

automatisk utregning av FIB-4-skår og implementering av de spesifikke

fibrosetestene vi trenger for å følge de internasjonale retningslinjene»

ELF-test er bredt validert som fibrosetest og prognostisk prediktor med bedre treffsikkerhet enn FIB-4-test for en rekke kroniske leversykdommer (13,14.). I britiske retningslinjer anbefales ELF-test for fibrosetesting ved ikke-alkoholisk leversykdom. Vi oppfordrer laboratorietjenesten ved norske sykehus til å sørge for automatisk utregning av FIB-4-skår og implementering av de spesifikke fibrosetestene vi trenger for å følge de internasjonale retningslinjene.

Leverstivhetsmåling er en etablert metode for estimering av fibrosegrad ved en rekke kroniske leversykdommer. Målingen kan gjøres ved FibroScan-apparat, ultralydelastografi eller MR-basert elastografi (MRE), og utføres av sykepleier (FibroScan), radiolog, gastroenterolog eller annet helsepersonell med opplæring enten i primærhelsetjenesten, integrert i poliklinisk kontroll eller som egen undersøkelse ved røntgenavdelingen.

Leverstivhetsmåling med FibroScan er best validert og kan utføres av sertifisert sykepleier eller lege etter relativt kort opplæring, men krever et eget apparat. Ultralydelastografi tilbys som tilleggsapplikasjon for de fleste avanserte ultralydplattformene. FibroScanapparat eller ultralydelastografi finnes ved noen sykehus i alle helseregioner, mens MRbasert elastografi ikke er klinisk tilgjengelig i Norge.

Vi mener at leverstivhetsmåling bør utføres rutinemessig som ledd i undersøkelsen når pasienter henvises til ultralyd av lever, enten henvisningsårsaken er utredning for leversykdom eller oppfølging av steatose eller annen kronisk leversykdom. Leverstivhetsmåling gjøres også hos barn.

\section{«Leverstivhetsmåling bør utføres rutinemessig som ledd i undersøkelsen} når pasienter henvises til ultralyd av lever»

Både ELF-test og leverstivhetsmåling skiller mellom pasienter med og uten cirrhose med høy negativ prediktiv verdi (15). De skiller også godt mellom pasienter med og uten signifikant fibrose. Både geografisk spredning og kapasitetshensyn tilsier at vi bør basere oss på ELF-test og elastografi som komplementære alternativer i fibrosediagnostikken i Norge.

\section{Gjennomføring i praksis}

Vi inviterer våre kolleger i primærhelsetjenesten, endokrinologer og kardiologer som følger personer med type 2-diabetes eller overvekt - og ikke minst spesialister innen medisinsk biokjemi og radiologi - til dialog for å etablere systematisk diagnostikk og oppfølging av pasienter med alkoholrelatert og overvektsrelatert leversykdom. Denne kronikken er ment som et utgangspunkt for denne dialogen.

Vi mener at personer som tilhører risikogruppene, må følges med FIB-4-skår som markør for leverfibrose like selvsagt som vi måler glomerulær filtrasjonsrate eller henviser personer med type 2-diabetes til øyevurdering. Dette må følges opp med mer spesifikke fibrosemålinger ved behov. Pasienter med progressiv leversykdom bør henvises til oppfølging hos gastroenterolog. FIB-4-skår bør gis som rutineprøvesvar ved alle landets laboratorier, og ved større sykehus er det en selvfølge at ELF-test blir en del av analysetilbudet. Elastografitilbudet og -kapasiteten er i dag utilstrekkelig og bør bygges ut. 
Alkohol- og overvektsrelatert leversykdom må anerkjennes som et folkehelseproblem. Strategier for å fange opp pasienter med høy risiko for progressiv leversykdom må innarbeides i de nasjonale faglige retningslinjene for diabetes, kardiovaskulære sykdommer og overvekt hos voksne samt i nasjonale handlingsplaner for fysisk aktivitet, overvekt og diabetes.

\section{LITTERATUR}

1. Karlsen TH, Sheron N, Zelber-Sagi S et al. The EASL-Lancet Liver Commission: protecting the next generation of Europeans against liver disease complications and premature mortality. Lancet 2022; 399: 61-116. [PubMed][CrossRef]

2. Younossi ZM, Koenig AB, Abdelatif D et al. Global epidemiology of nonalcoholic fatty liver diseaseMeta-analytic assessment of prevalence, incidence, and outcomes. Hepatology 2016; 64: 73-84. [PubMed][CrossRef]

3. Croci I, Coombes JS, Bucher Sandbakk S et al. Non-alcoholic fatty liver disease: Prevalence and allcause mortality according to sedentary behaviour and cardiorespiratory fitness. The HUNT Study. Prog Cardiovasc Dis 2019; 62: 127-34. [PubMed][CrossRef]

4. Goldberg D, Ditah IC, Saeian Ket al. Changes in the Prevalence of Hepatitis C Virus Infection, Nonalcoholic Steatohepatitis, and Alcoholic Liver Disease Among Patients With Cirrhosis or Liver Failure on the Waitlist for Liver Transplantation. Gastroenterology 2017; 152:1090-1099.e1. [PubMed] [CrossRef]

5. Lindvig KP, Hansen TL, Madsen BS et al. Diagnostic accuracy of routine liver function tests to identify patients with significant and advanced alcohol-related liver fibrosis. Scand J Gastroenterol 2021; 56:1088-95. [PubMed][CrossRef]

6. Harman DJ, Ryder SD, James MW et al. Direct targeting of risk factors significantly increases the detection of liver cirrhosis in primary care: a cross-sectional diagnostic study utilising transient elastography. BMJ Open 2015; 5: eoo7516. [PubMed][CrossRef]

7. European Association for the Study of the Liver (EASL), European Association for the Study of Diabetes (EASD), European Association for the Study of Obesity (EASO). EASL-EASD-EASO Clinical Practice Guidelines for the management of non-alcoholic fatty liver disease. J Hepatol 2016; 64: 1388402. [PubMed][CrossRef]

8. Younossi ZM, Golabi P, de Avila L et al. The global epidemiology of NAFLD and NASH in patients with type 2 diabetes: A systematic review and meta-analysis. J Hepatol 2019; 71: 793-801. [PubMed] [CrossRef]

9. Åberg F, Helenius-Hietala J, Puukka P et al. Interaction between alcohol consumption and metabolic syndrome in predicting severe liver disease in the general population. Hepatology 2018; 67: 2141-9. [PubMed][CrossRef]

10. Blomdahl J, Nasr P, Ekstedt M et al. Moderate alcohol consumption is associated with advanced fibrosis in non-alcoholic fatty liver disease and shows a synergistic effect with type 2 diabetes mellitus. Metabolism 2021; 115: 154439. [PubMed][CrossRef]

11. European Association for the Study of the Liver. EASL Clinical Practice Guidelines on non-invasive tests for evaluation of liver disease severity and prognosis - 2021 update. J Hepatol 2021; 75: 659-89. [PubMed][CrossRef]

12. Mansour D, Grapes A, Herscovitz M et al. Embedding assessment of liver fibrosis into routine diabetic review in primary care. JHEP Rep 2021; 3: 100293. [PubMed][CrossRef]

13. Parkes J, Roderick P, Harris $S$ et al. Enhanced liver fibrosis test can predict clinical outcomes in patients with chronic liver disease. Gut 2010; 59: 1245-51. [PubMed][CrossRef]

14. Sanyal AJ, Harrison SA, Ratziu V et al. The Natural History of Advanced Fibrosis Due to Nonalcoholic Steatohepatitis: Data From the Simtuzumab Trials. Hepatology 2019; 70:1913-27. [PubMed][CrossRef]

15. Rasmussen DN, Thiele M, Johansen S et al. Prognostic performance of 7 biomarkers compared to liver biopsy in early alcohol-related liver disease. J Hepatol 2021; 75: 1017-25. [PubMed][CrossRef]

Publisert: 27. januar 2022. Tidsskr Nor Legeforen. DOI: 10.4045/tidsskr.21.0892

Mottatt 15.12.2021, godkjent 7.1.2022.

(C) Tidsskrift for Den norske legeforening 2023. Lastet ned fra tidsskriftet.no 26. april 2023. 